\title{
COMment/Commentaire
}

Reply to "Response to 'Anxious Academics: Mission Drift and Sliding Standards in the Modern Canadian University' by James Côté and Anton Allahar." Canadian Journal of Sociology 2008 33(2):418-420 http://ejournals.library.ualberta.ca/index.php/CJS/article/view/1992/1413

ames Côté and Anton Allahar claim that my review essay, "Anxious

Academics: Mission Drift and Sliding Standards in the Modern Canadian University" (CJS 33, 3 (2008): 404-417 <http://ejournals.library. ualberta.ca/index.php/CJS/article/view/1991/1412>) was full of "egregious" distortions that bear little resemblance to their ideas in Ivory Tower Blues: A University System in Crisis. They claim that my reading was "mischievous" and "poor" because I fundamentally did not understand that the book was intended for at least two audiences: one the general public, the other academic. I must demur, of course, but in their defence negative reviews are never easy to read.

My central point was quite simple. Côté and Allahar have some compelling things to say about student disengagement as measured by NSSE, and they have made some perhaps more obvious observations about current dynamics in the classroom, especially at large research institutions where teaching can take a back seat. But as an argument about the "crisis" in postsecondary education in Canada their book lacks depth and nuance and its superficiality is all the more evident when one compares it with a serious and complex book such as George Fallis's Multiversities, Ideas, and Democracy, reviewed in the same essay.

Ivory Tower Blues relies on popular social science literature about the "millennial generation" that characterizes students as arrogant and self-indulgent, with oversized senses of entitlement, and scant awareness of personal limits or responsibility. One expects more from critical sociologists than such facile characterizations. At the very least, one expects them to problematize bloated and overarching generalizations even as they write a popular book.

The overwhelming sense of Ivory Tower Blues is one of blame, both of students and of high schools for not preparing students for higher education and creating the illusion of student progress through inflated grades. I don't deny that grade inflation may be a problem. I simply noted that our educational institutions have withstood tremendous so- 
cial and cultural changes over the past thirty years and they have done remarkably well, especially in openness and accessibility. The authors' emphasis on grade inflation neglects the advances that women and minorities have made within our liberal democratic educational institutions.

The challenges continue to be significant, especially for universities. The growing corporatization of higher education, which the authors have acknowledged, is surely a more profound problem than grade inflation. But even when the authors discuss the dangers of "edubusiness" and vocationalism to liberal education, their arguments are laden with the paternalistic view that universities are the bearers of traditional, "universal" knowledge that students should soak up with the help of their professorial guides.

Côté and Allahar take umbrage that I linked their ideas about education and students to neoconservative ideologues who have made similar arguments about the "narcissism" of the current generation and the "political correctness" one finds in the contemporary university. "We are not neoconservatives," they insist. Yet there is very little to distinguish their ideas from those of Allan Bloom in The Closing of the American Mind. Perhaps Côté and Allahar will agree with me that ultimately, it's best to let the reader decide.

University of New Brunswick, Saint John

Joe GALBo

\section{Reply to Joseph Galbo}

Joseph Galbo has gone to great lengths to attempt to discredit our book. One explanation for his doggedness is that we didn't write the book he wanted. His rejoinder leaves the impression that he wanted a book only on the corporatization of the university and not about how corporatization contributes to grade inflation and disengagement. Well, there are plenty of books about the former, but none about the latter. Even so, Galbo fails to acknowledge our argument that grade inflation and academic disengagement are products of corporatization. This argument is laid out on pages 64 through 95 where we describe life in the "credential mart" (and where we describe the evolution of the consumeroriented university), and on pages 123-126, where we discuss the rise of "edubis" and its consequences for grading practices and standards.

In his review, Galbo claimed that we present the popular conception of the so-called millennial generation as "an accurate portrait of a generation." In his rejoinder, he expands this thrust by claiming that our book "relies" on the notion of the millennial generation in its least complimentary representations. Readers can evaluate this claim in the 
opening pages of chapter 3 , where we first discuss the proliferation of theories about the changing transition to adulthood, noting the various monikers dubbed on the current cohort. We then go on to briefly explain our approach to Youth Studies, which emphasizes the deteriorating financial conditions associated with the transition to adulthood over the past several decades (published in books like Generation on Hold [1994] and Critical Youth Studies [2006]). After briefly explaining that our approach looks to the roots of problems facing young people as well as the consequences, we note that popular approaches focus mainly on the consequences of these problems without understanding their roots. We then describe one of these approaches, that of a noted pædiatrician Mel Levine, as a way of understanding "the more severely disengaged student, but not the more engaged students" (p. 98, emphasis added). After explaining Levine's approach, we caution readers that we "present this characterization not to put young people down or to over-simplify them" (p. 103), but to help us understand why some students might experience problems of disengagement in university. And, in the next paragraph we stress that "as sociologists we recognize the difficulties inherent in using generational analyses" (p. 103) and devote two paragraphs to explaining these difficulties to the reader and why it is more useful to use empirically validated typologies.

If our book relies on anything, it is an empirically derived typology of student engagement based on NSSE results, not the popular literature on the "millennial generation." In fact, we used the expression "millennial generation" on only a half dozen pages of this 251-page book, and then prefaced it with the phrase "so called" several times to show our caution in using the term. Furthermore, contrary to Galbo's assertion, nowhere in the book is this cohort referred to as narcissistic; in fact, the word narcissism does not appear in the book at all.

Not satisfied with these misrepresentations, Galbo goes on to assert that "the overwhelming sense" of our book "is one of blame ... of students" To the contrary, we went to great lengths to deflect the blame from current students, by reminding readers in several places that this is not our intention nor should readers fall into that trap. For example, on page 101 we state: "Let us be clear ... that we are not blaming the situation we are describing on some sort of character defect of the current generation of students. These students are responding to structural influences beyond their control, structural influences that we ourselves have been observing over the past several decades." We go on to note that we wrote the book to stimulate a public debate about the problems experienced in our universities, and in several places we show how the system is set up to "cool out" students: convince those who do not well to blame them- 
selves for their failures rather than the system that orchestrates those failures. Galbo scolds us for not living up to our reputation as "critical sociologists," a jab that is consistent with his caricature of our book.

We teach our students that a good book review conveys to readers more about the book than the reviewer. Galbo tells readers very little about our book, but much about who he thinks he is and what he wants to defend.

University of Western Ontario James Côté ANd Anton Allahar 